\title{
Self-Defense, Proportionality, and Defensive War against Mitigated Aggression
}

\section{Jacob Blair \\ CSU East Bay}

\begin{abstract}
A nation commits mitigated aggression by threatening to kill the citizens of a victim nation if and only if they do not submit to being ruled in a non-egregiously oppressive way. Such aggression primarily threatens a nation's common way of life (CWL). According to David Rodin, a war against mitigated aggression is automatically disproportionate, as the right of lethal self-defense only extends to protecting against being killed or enslaved. Two strategies have been adopted in response to Rodin. The first strategy grants that CWL is insufficiently valuable to lethally defend, however, other considerations can satisfy the proportionality requirement. I argue that this strategy is not persuasive. The second strategy argues for the sufficient value of CWL. This, however, fails to answer the forceful 'benign dictator' objection. I respond to this objection by grounding the proportionality of a defensive war in the value of what Phillip Pettit calls 'anti-power'.
\end{abstract}

KEYWORDS: Anti-Power, Defensive War, Mitigated Aggression, Proportionality, Self-Defense

\section{INTRODUCTION}

Say you are taking a stroll in the park and an attacker suddenly tries to kill you. SThere's a strong intuition that you are permitted to kill your attacker if that is the only way to save your life. Now consider a different case where you are kidnapped and made to be a slave. Many people would seemingly claim that you are permitted to kill the assailant if that were the only way to escape, but seemingly a good number of people would also claim their intuitions are less strong than in the previous case; and it seems that more people than in the previous case would deny that you are permitted. Let's change the case again and say someone will kill you if you don't allow him to slap you or if you don't hand over your 
car (you are confident that he will let you live if you give him what he wants). I suspect that a good of number of people would be inclined to think that you are not permitted to kill your attacker here. The point of these examples is to illustrate that it's not obvious that the right of lethal self-defense extends to everything that we highly value. Sometimes killing aggressors is seemingly a disproportionate response to their aggression: the harm given them is excessive compared to the harm that they threaten.

Consider the realm of nations and assume that a nation exercising its right to national-defense just is the people of that nation (usually its soldiers) collectively exercising their right of self-defense. ${ }^{1}$ Say one nation invades another but the goal in invading is not to commit genocide, nor is it to enslave the victim nation. Rather, the goal in invading is to conquer and rule. Like the robber, the aggressive nation will kill the citizens and soldiers of the victim nation if and only if they resist being ruled. And again, being ruled in this case doesn't consist in being the property of a brutal, oppressive regime. Call this kind of aggression, mitigated aggression. ${ }^{2}$ What mitigated aggression threatens is a nation's political sovereignty and perhaps cultural integrity, in short, a nation's common way of life. The question is whether a nation's common way of life is sufficiently valuable so that the right of lethal self-defense extends to it. It's not obvious that it does, for again, it's not obvious that the right of lethal self-defense extends to everything that's highly valuable.

David Rodin says that we are hard pressed to claim that the right of lethal self-defense extends to a nation's common way of life. For Rodin, this right doesn't extend beyond protecting against being killed or enslaved and the burden of proof is on those who think it does. ${ }^{3}$

In the literature, two main strategies have been adopted in order to shoulder this burden of proof. Proponents of the first strategy, Jeff McMahan and Thomas Hurka, grant Rodin the premise that a nation's common way of life by itself is insufficiently valuable to defend via lethal force. They claim, however, that other considerations can still render a defensive war against mitigated aggression proportionate. In the first part of this paper I discuss their three specific arguments and conclude that they are not persuasive.

The proponent of the second strategy, Deane-Baker Peter, seeks to show that a nation's common way of life by itself is sufficiently valuable to defend via lethal force. He has seemingly shown this but he fails to answer a common objection, which states that many (perhaps most) cases of mitigated aggression actually leave a nation's common way of life sufficiently intact. In the second part of this paper I briefly discuss Baker's argument and the objection to it; I also suggest an answer: the issue is ultimately subjugation as opposed to the value of the common way of life. A mitigated aggressor can still subjugate a victim nation even if it doesn't actually interfere extensively with its common way of life. The right of lethal self-defense, moreover, can be exercised to thwart subjugation, thus a defensive war against mitigated aggression can be proportionate. 


\section{JUS AD BELLUM PROPORTIONALITY}

Before analyzing the three arguments by McMahan and Hurka, I will briefly discuss the nature of proportionality relevant to this paper and its relation to warfare. I take the jus ad bellum (justice of war) proportionality requirement to be saying the following: the resort to defensive war is disproportionate (and therefore unjust) just in case the total amount of expected evil that stems from the relevant bad consequences of the war greatly outweighs the total amount of expected goodness that stems from the relevant good consequences of the war. ${ }^{4}$ This conception of ad bellum proportionality is not uncontroversial. Some, for example, would drop the term "greatly" from this conception; and some claim a war is disproportionate just in case the total amount of goodness does not outweigh the total amount of evil. ${ }^{5}$ Whatever the precise conception of ad bellum proportionality, my claim is that the three arguments below have not shown that a defensive war against mitigated aggression can be proportionate.

\section{The Good and Bad Consequences of War:}

But what are the relevant good and bad consequences of a war that are to be weighed against each other in the proportionality calculus? Traditionally (and intuitively) there is no distinction between an evil consequence of war and a relevant evil consequence of war. ${ }^{6}$ When assessing the overall justification of a resort to war, all of the bad effects a war may cause - the death and suffering of civilians, the damage to infrastructure, the destruction of the environment, for example, need to be weighed against the relevant good effects to be achieved.?

Of particular interest to this paper is the question of 'what is to count as a relevant good effect of a defensive war'? A relevant good that is to be counted in the proportionality calculus is the achievement of the just cause. Many just war theorists agree that a war that has a just cause is a defensive one (and only a defensive one) that is waged in order to protect people from having their political or basic human rights violated.

But are there other good effects of war that can be factored into the proportionality calculus? What if a resort to defensive war would likely deter other nations from committing aggression? Or, similarly, what if a defensive war not only defeats (or pushes back) the aggressive army, but incapacitates it so as to prevent it from committing future aggression? What if resort to war brought about scientific advancement, or a world wide economic boom, or the satisfaction of many soldiers who are anxious to defend their country? Perhaps we can label the realization of these things as good, but the question is whether or not they should count as relevant goods to be weighed against the evils of a particular war. It is not obvious to me that any of these should be counted as relevant goods. This seems especially true concerning the benefits of desire fulfillment as well as scientific and worldwide economic advancement. It's hard to see how these things could ever contribute to the justification of maiming and killing.

McMahan and McKim argue that the benefits of deterrence and incapacitation can count as relevant goods. They do this by distinguishing between a sufficient and a contributing just cause for war. ${ }^{9}$ A sufficient just cause is one that, by itself, 
satisfies the just cause condition for justified warfare. Thus, defense against aggression (whether it is defending one's own countrymen or citizens of another country) counts as a sufficient just cause. Here the goal, which is all things equal permissible to pursue by means of war, is the defeat of the aggressive army; fending the enemy off so that they either choose to discontinue the aggression, or are (for the short term) incapable of continuing the aggression.

Contributing just causes do not by themselves satisfy the just cause condition for warfare, but they do contribute to the justification of warfare once a sufficient just cause is established. The goals of incapacitating (or we might say disarming) the aggressive army so as to prevent it from committing future aggression, as well as deterring other aggressive nations are thought to count as contributing just causes. Incapacitation and deterrence, then, are thought to be relevant goods to be achieved by warfare; and thus qualify to be a part of the proportionality calculus. ${ }^{10}$

But why think that a nation that possess a sufficient just cause for war is permitted to pursue the goals of deterrence and incapacitation by means of war, even if pursuing these additional goals requires military force that goes beyond what is needed to merely realize the sufficient just cause? For McMahan and McKim, the justification can be found when we examine the practice of punishing criminals. ${ }^{11}$

There are a number of different reasons why law enforcement seeks to punish criminals by incarceration. Two primary reasons include incapacitating the convicted criminals from committing further crimes as well as deterring other would be criminals from committing the same or similar crimes. The idea is that the sentence handed down to a criminal is harsher than it would have been had deterrence and incapacitation not been ends to achieve through punishment. Once someone does commit a crime, the goal of punishment goes beyond merely keeping him from committing crime in the short term. The goal now includes taking measures so as to keep him from doing it again in the long run as well as dissuading other would be criminals. In the same way, once a nation has committed aggression on another (making it so the defending nation has a sufficient just cause for war), a nation is permitted to wage a defensive war with the goal of not only thwarting the aggression, but of disarming the aggressive army and deterring other would be aggressors.

\section{THE ARGUMENT FROM CONTRIBUTING CAUSES}

So how does this discussion relate to the view that defensive war against mitigated aggression can be proportionate? We could claim that a defensive war against mitigated aggression can be proportionate given that deterrence and incapacitation are to be counted in favor of such a war being proportionate. We concede that the harm to be avoided while serious (we'll grant that we have a sufficient just cause) is not serious enough to warrant the killing of anyone who threatens the harm. However, when we realize that a defensive war against mitigated aggression can also accrue the benefit of deterring other would be aggressors and incapacitating the actual aggressor, it's possible for the defensive war to become proportionate. Other bad consequences could in the end render the defensive 
war disproportionate, but a defensive war against mitigated aggression is not necessarily disproportionate. ${ }^{12}$

This argument problematically utilizes an analogy with punishment given that national-defense just is the collective form of self-defense. The differences between punishment and self-defense are significant. Some think, for example, that legitimate punishment requires that the one punishing have the appropriate authority over the one being punished. The point is that we can't claim that something can be true in situations of collective self-defense because it also true in situations of punishment.

In fact we do not think that a part of our goal in employing defensive force on an attacker is both to prevent him from harming us (and/or others) in the future and deter others from aggression. Rather, our goal is simply to prevent an attacker from harming us (and/or others) in the present. The necessity requirement on self-defense, for example, seemingly rules out conceiving of incapacitation as part of the goal of self-defense. Necessity roughly requires that an action I undertake in order to protect $X$ is the least harmful means of protecting $X .{ }^{13}$ If I can escape my attacker by knocking him unconscious rather than paralyzing him, I must do the former, regardless of the good consequences that may result if I do the latter, e.g., incapacitating my attacker so he is unable to hurt me or others in the future. (Again, the assumption is that the victim nation [or state] is not an agent in its own right, holding and exercising rights of its own, e.g., the right of national-defense. Thus I take it that a victim nation carrying out a defensive war is not the type of thing that can have goals that are different than the goals of the persons that both comprise the nation and carry out the war). ${ }^{14}$

Problems remain even if we grant that deterrence and incapacitation qualify as relevant goods of a defensive war. Killing a thief in order to stop him from stealing my car seemingly constitutes a disproportionate use of force. Surely by killing him he would be incapable of stealing again and other would be thieves would be deterred from trying to steal from me. But these benefits seemingly do not justify me in killing the thief. In the same way, it's contrary to our intuitions about justice to claim that mitigated aggressors are strictly speaking immune to receive lethal force but that a defending nation is nonetheless justified in employing lethal force against them in order to both ensure that they are not a threat to international security, and that other potential aggressive nations are dissuaded from aggression. ${ }^{15}$

\section{THE ARGUMENT FROM ANTICIPATION}

The things mitigated aggression seeks to take away are not sufficiently important to defend via lethal force but it doesn't follow that a defensive war is necessarily disproportionate. Consider the mugger who threatens to kill me if I don't hand over my car. At first blush, it's not clear that I am permitted to straightway kill the mugger in defense of my car. But it is clear that I am permitted to do something (short of killing) to defend my car, e.g., kick the mugger in the shins. I also know that if I were to do this, the mugger would unjustifiably respond by killing me. Since I know in advance that the mugger will unjustifiably try and kill me in re- 
sponse to my permissible action, it would be extremely foolish of me to kick him in the shins and run the very high risk of being killed. But surely the mugger has not confined me to only one morally acceptable response, that being capitulation. Thus I am permitted, despite initial appearances, to kill the mugger straightway, not only in defense of my car but also in anticipation of his likely lethal response to any permissible defensive action I would undertake. ${ }^{16}$ The same applies to any victim nation facing mitigated aggression.

This argument seemingly proves too much. Say I am acquainted with an eccentric and disturbed yet fully rational individual who threatens to kill me if I don't hand over the quarter in my pocket. I know that this individual is a vicious bully and that he would jump at any opportunity to kill me if I didn't give him what he wants. But I also know that his viciousness subsides when he gets his way; thus I'm confident that he won't try and kill me if I give him the quarter. ${ }^{17}$ Surely the authorities should be notified about this individual, but seemingly I am not permitted to respond by killing him; that it's a quarter he's after makes killing him a disproportionate response. ${ }^{18}$ By this argument's own lights, however, it's a proportionate and therefore permissible response.

Consider a slightly different case. I'm in line at the coffee shop and a man intentionally begins to inch his way in front of me. In defense of my position I can say a sharp word or perhaps extend my arm out so as to block his way in. I'm fairly confident that if I were to do this, he would land a few hard punches that could very well knock me unconscious. As he's cutting in line, would it be proportionate to straightway knock him out? It seems to me, 'No', despite him being atrociously offensive. And yet doing so would not only secure my position in line but also be an anticipatory action to how he would have responded to my mildly aggressive yet justified response. The argument from anticipation seemingly makes the proportionality requirement on self-defense too permissive.

It could be claimed that things like quarters and places in line are insufficiently valuable to warrant these anticipatory-defensive responses. But this seems arbitrary. What is it that makes something like my car but not my quarter sufficiently valuable? I take it that a part of the motivation for employing the argument from anticipation (and the argument from cumulative offenses; see below) is that one is not required to address the difficult question of what other than one's life is, by itself, sufficiently valuable to lethally defend. But it seems the argument from anticipation leaves us with basically the same kind of question. Presumably cases can be given in order to elicit intuitions about what types of things warrant a lethal anticipatory-defensive response. What if, for example, someone threatened to kill me if I didn't let him break my arm? I suspect many people would be inclined to think that one could straightway kill one's attacker. But any example that elicits widespread intuitions seemingly won't involve things that are clearly insufficiently valuable, by themselves, to warrant a lethal response. In other words, it could be that I am permitted to lethally defend against an intentional attack on my arm even without the attacker threatening my life, and even knowing that the attack will not kill me. Because any compelling case that would show something valuable enough to warrant a lethal anticipatory-defensive response would also seem 
to show that it by itself warrants a lethal defensive response, it's not clear that such a case would lend significant support to the argument from anticipation.

Regarding the case of my car, the claim is that I've employed proportionate force by killing the mugger. But have I really employed proportionate defensive force? It's somewhat controversial whether anticipatory force qualifies as defensive force. An instance of anticipatory force counts as permissible defensive force only if it will prevent an actual imminent threat. ${ }^{19}$ Killing the mugger would not prevent an actual imminent threat to my life. It's not clear, then, how the defense of my life can factor into the justification for killing the mugger. What is leftover to make my act of killing proportionate is my car, but it's already admitted that my car, by itself, cannot render my killing proportionate.

Finally, what if there is no effective police authority to protect me from someone who continually threatens me for my quarters, cars, etc? This sounds like a sort of state of nature, which more closely resembles the international scene. It's not clear that I am obligated to continually capitulate here. But this scenario doesn't support the argument from anticipation. For in this context my assailant is harming and interfering me in a more egregious way (and what is taken from me has little chance of being recovered, making it more valuable). Thus it seems that if I am permitted to kill my assailant, what I am defending is by itself worthy of a lethal response. ${ }^{20}$

\section{THE ARGUMENT FROM CUMULATIVE OFFENSES}

Thomas Hurka presents a forceful cumulative case for why, in some cases, a defensive war against mitigated aggression can be proportionate. He claims that some instances of mitigated aggression have three features that when taken together justify a defending nation in responding with lethal force. ${ }^{21}$

\section{Feature}

The first feature Hurka mentions is the fact that sometimes a vast number of people will have their right to political self-determination ${ }^{22}$ violated and most likely for a long period of time. This fact justifies a moderate boost in the amount of force employed against such aggression, even though the amount does not reach the level of lethal force. The amount of force employed here is more than what is permitted to be used in response to only a handful of people having their right to political self-determination violated, and that for only a short period of time. Analogously, for Hurka, one person is not permitted to break the arm of a tickler in order to prevent himself from being tickled; however, a large enough group of people is permitted to break the arm of a tickler to keep from being tickled. Similarly, concerning duration, I am not permitted to break someone's arm in order to keep from being confined against my will for five minutes. But I am permitted to do this and more if that is the only way to keep from being confined for, say, fifty years. ${ }^{23}$

Given these examples, Hurka is seemingly adopting a moderate view of rights, which roughly says any given right can permissibly be infringed when there is a large amount of substantial good at stake..$^{24} \mathrm{~A}$ person has certain rights 
that are intended to protect him from various harms, even if benefits will accrue to people if his right is infringed. However, rights are not absolute. Each right has a 'threshold' such that it can sometimes 'give way' if enough people can (by having the right 'give way') be spared from experiencing certain harms that are at least as bad or in some cases not as bad as the harm that the particular right bearer will experience upon having his right infringed. ${ }^{25}$ Regarding the 'tickle' example, we can ask: can a tickler's right to life be infringed if that is the only way to keep a large number of people from being tickled? The answer for Hurka (and most moderates) is clearly No; "not even a million people can kill to save themselves from that trivial a threat." ${ }^{26}$ But again, a tickler's right to not have his arm broken can be justifiably infringed if that is the only way to keep some very large number of people from being tickled.

\section{Feature 2}

The second important feature of mitigated aggression is that it involves a conditional threat issued by the aggressor. The nature of this threat increases (somewhat) the amount of force that can be employed in response to it, even though the amount fails to rise to the level of lethal force. The mugger conditionally threatens my life in that he threatens to kill me if I don't hand over my car. The mugger performs a single act that violates me in a way that is less serious than a direct attempt on my life but more serious than a mere attempt (absent any sort of threat to kill me) to take my car. Thus, the amount of force I am permitted to employ in defense of my car, in the face of a conditional threat, is more than what I am permitted to employ in response to a mere attempt at my car, but less than what I am permitted to employ in response to a direct attempt at my life. ${ }^{27}$

\section{Feature 3}

Finally, Hurka claims that all international aggression (mitigated included) is analogous to someone invading another's home. A person's home, while it is his property, is something much more than that. It is his personal and private space in which to experience security. For an intruder to enter it is to violate that personal and private space. The amount of force one is permitted to employ on intruders of one's home is seemingly more than the amount one is permitted to employ in defense of one's property in general.

Similarly, people view their own country as a home of sorts. A national home is a place to experience security. Furthermore, citizens of a country are emotionally attached to its cultural way of life. To be invaded by another country is like having one's home burglarized. For Hurka, then, "it is a mistake to see the only rights of citizens threatened by [mitigated] aggression as rights of political selfdetermination [referring here to feature 1]; they also include the right to be secure in a political and cultural home. ${ }^{28}$ Because of this, the amount of force a defending nation is permitted to employ is increased somewhat. ${ }^{29}$

Importantly, for Hurka, each of these three features of mitigated aggression in isolation is not sufficient to justify a lethal defensive response; however, all of them together do justify such a response. For all of these features taken together entail that the threat of the aggressive nation is sufficiently egregious to warrant 
a lethal military response. Thus when (and only when) these features are present in mitigated aggression, a defending nation is certainly permitted to kill in response to it.

In response to Hurka, even if we accept his argument, it cannot account for the widespread belief that an undemocratic nation is permitted to defend itself from mitigated aggression. In such a case, features 2 and 3 are present but feature 1 is not. Hurka admits that his argument leaves him problematically agnostic as to whether or not a nation like Kuwait is permitted to lethally defend itself against mitigated aggression, e.g., the invasion by Iraq in the early 1990s, assuming that was an instance of mitigated aggression. ${ }^{30}$

Regarding feature 1, I take Hurka to be saying that a nation is justified in elevating the amount of defensive force it employs just in case it is large in size, democratic, and faces being occupied for a sufficiently long time ${ }^{31}$ Kuwait presumably only fulfills the last condition, thus it fails to satisfy feature 1. Kuwait does not enjoy democratic liberty, thus it's not clear that enough is at stake to warrant a defensive war. Even if Kuwait were a large nation, it still wouldn't have enough at stake to justify such a war.

For Hurka, if we want to say with definitiveness that a war against mitigated aggression is to be proportionate, the war in question at least must have as a good consequence the protection of a great number of people's democratic liberty. But this doesn't seem right. Many of the world's nations are undemocratic. There is, it seems to me, something particularly unsavory about a view in defense of lethal force against mitigated aggression that cannot say why an invasion of these countries (large or small) is sufficiently serious to warrant a defensive response. (Hurka's view also has the odd consequence of not being able to say why a small democratic nation is justified in lethally defending itself).

Perhaps Hurka has shown that a large democracy is permitted to defend itself from mitigated aggression, but he has seemingly shown this at a high cost. To see this, take any case of mitigated aggression involving aggressive nation $\mathrm{A}$, and victim nation V. I make the empirically plausible assumption that feature 3 will likely be met: the people of $\mathrm{V}$ will feel as though their home is being invaded. Furthermore, feature 2 will be satisfied in virtue of the definition of mitigated aggression. What remains to be seen, then, is whether $\mathrm{V}$ is sufficiently large and democratic to 'tip the scales' so as to justify it in rendering a lethal response. Let's assume that $\mathrm{V}$ is a sufficiently large democracy. Hurka's claim is that the soldiers that constitute A's army can have their right to life justifiably infringed by the soldiers of V. I have two concerns. First, recall Hurka's intuition that a person's right to not have his arm broken can be justifiably infringed if such an infringement kept some very large number of people from being tickled. Importantly, the person who has his arm broken has not forfeited this particular right. He still retains it; it's just that, given the extraordinary circumstances, it is permissible for one to act as if the right bearer didn't have the right. It is in this sense that the right is infringed or overridden as opposed to violated, where failing to accord the right in question would be morally wrong. Because the right bearer has not done anything to forfeit this right, it is still the case that significant compensation should be owed to the particular right bearer (the right infringer should, for example, pay for the 
doctor's bill). What are the implications for warfare? $\mathrm{V}$, for example, would be permitted to lethally defend itself against A; but it would also problematically owe A significant compensation for taking up arms to defend itself.

Secondly, regarding $\mathrm{V}$, it would seem that it's not just the vast number of people (and all they stand to lose) that permits them to use lethal defensive force. Rather, it is the vast number of people (and all they stand to lose) in relation to the significantly lower number of people (aggressors that constitute the military of A) that have a right to life. The intuition behind the examples that are meant to suggest that rights have thresholds is the idea that in some cases a very small number of people can have their rights infringed if that means some vastly larger number of people can either be saved from having their rights violated (which are less stringent than the rights that are to be infringed) or be saved from receiving a harm that is not as serious as the harm that the smaller group of people will experience.

So what does this mean? If we claim that a large democracy can permissibly kill in order to defend itself from being conquered and ruled (a lesser harm than being killed), then seemingly the number of aggressors would have to be quite small compared to the number of victims. We seemingly do not want to say that the people of a large democracy are permitted to defend themselves, but only when they significantly outnumber their enemy. Or, that they can only defensively kill an extremely small number of aggressors compared to the number of people that are kept from harm by their defensive efforts.

Perhaps Hurka is better interpreted as saying that the soldiers of A forfeit their right to life with respect to the soldiers of $V$ just in case features 1 through 3 are satisfied. But if this is the case, I again find it difficult to say that the crime of mitigated aggression towards the Kuwaitees, for example, is less egregious than the same crime towards the Canadians let's say. ${ }^{32}$ Or that a small democracy is not permitted to defend itself but a large sized one is.

\section{LETHALLY DEFENDING THE COMMON WAY OF LIFE}

The foregoing discussion shows that the best way to answer Rodin is to demonstrate that a nation's common way of life by itself is worth lethally defending, and this regardless of whether the nation is large or not, democratic or not. It seems that Deane-Peter Baker has successfully answered Rodin in this way. ${ }^{33}$ Foundational to Baker's argument is Martha Nussbaum's ten central human functions: ${ }^{34}$ Some of these include: life, bodily health, and bodily integrity. Of particular importance is practical reason: "[b]eing able to form a conception of the good and to engage in critical reflection about the planning of one's life"; as well as affiliation: "being able to live with and towards others ... to engage in various forms of social interaction." For Baker, all human beings must realize to a certain degree the ten functions in order to live a truly human life. ${ }^{35}$ Thus, the right of personal selfdefense extends to these functions. Furthermore, mitigated aggression disrupts the common way of life that one experiences with one's countrymen, and it is this common way of life that is necessary if one is to realize the ten functions, particularly the functions of practical reason and affiliation. 
More specifically, mitigated aggression "undermines the exercise of practical reason that has led to the particular arrangement of things in that particular society." 36 The "particular arrangement of things" refers to the victim nation's institutions and apparatus of government that it has implemented for itself. Mitigated aggression replaces a nation's government with a foreign one and thus forces the individuals that comprise the nation to be ruled in ways that they have not in any sense consented to. Presumably, the invading regime will not reflect, in its laws, forms of government, and institutions, the shared values and practices of the people they seek to conquer and rule over. The policies of any state (in virtue of being a state) will be coercive and affect, to a substantial degree, the day-to day lives of the individuals living under it. The individuals that comprise the victim nation, then, will be unable to govern a significant portion of their lives. They will justifiably feel as though they are kept from exercising their autonomy, particularly in the area of how they should govern themselves collectively. ${ }^{37}$

There is an absence of a human kind of life for people who are forced to live their lives differently than they would consent to. Thus people are permitted to collectively exercise their right of lethal self-defense against an aggressive nation that seeks to take away their ability to govern the thrust of their own lives. Importantly, there's no reason to think that this permission is limited to persons who comprise democratic societies. It's dubious to claim that necessarily a nondemocratic state doesn't reflect the values and practices of its nation in its laws and forms of government. Walzer is seemingly right to claim that foreigners can't presume to know, in the absence of clear evidence to the contrary, that there automatically isn't a 'fit' between an authoritarian government and its people. ${ }^{38}$ For foreigners, looking upon a union of an authoritarian regime and its people, "don't know enough about its history, and they have no direct experience, and can form no concrete judgments, of the conflict and harmonies, the historical choices and cultural affinities, the loyalties and resentments, that underlie it." 39 The presumption should be that a nation-under a non-democratic state-has shaped its own political institutions according to its "accumulated historical experience and its inherited culture and traditions." 40 'Shaped', of course does not mean something like, "elected through democratic processes." Rather, nondemocratic political institutions are a natural outgrowth of the culture, religious convictions, opinions, habits, and feelings of the people. ${ }^{41}$

Mitigated aggression also threatens to keep individuals from realizing the function of affiliation. Baker claims that the "web of relations" we find ourselves in, qua members of a society, "underpin[s] our very identities." 42 Several thinkers have claimed that a person's national community in large part makes her the person that she is, and gives her a sense of meaning in life; it's central to her selfunderstanding. ${ }^{43}$ Our national community provides us with "a way of being in the world ... a way of meaningful thinking, acting, and judging." ${ }^{44}$ Importantly, we have a sense of shared fate with our national community; as it disintegrates, so does the understanding of the self. ${ }^{45}$ Likewise, if it is destroyed and another one ushered in, those who had shared it "have to undergo a process of cultural adaptation that is painful and disorientating while it's happening, and rarely wholly successful in its outcome." ${ }^{46}$ 


\section{AN OBJECTION: COMMON WAY OF LIFE IS LEFT INTACT}

While Baker has seemed to adequately answer Rodin, he hasn't adequately answered a common objection: many instances of mitigated aggression are not terribly extensive in scope. A benign dictator, for example, can occupy a nation, become the sovereign, and yet ensure that most of the laws, forms of government, and institutions of the victim nation remain intact. ${ }^{47}$ Or the invading regime can be careful to ensure that the new laws, forms of government, and institutions, reflect to a sufficient degree the shared values and practices of the people they seek to conquer and rule over. ${ }^{48}$

Likewise, the aggressive nation can control the influx of foreign migration and influence, thus ensuring that the national community of the victim nation is not significantly disrupted. Aggression can solidify a national community rather than disintegrate it. It's been said that Palestinian national identity has been strengthened since Israeli occupation, and that the same was true of Polish identity after Nazi occupation.

Ultimate control over a victim nation's natural resources is a primary motivation to commit mitigated aggression. But even here an aggressor can allow a victim nation to appropriate a sufficient amount of its natural resources. We can also imagine an aggressor helping its victim nation to "develop" so that the victim nation is able to utilize more of its resources for itself

Seemingly most people would say that these instances of mitigated aggression warrant a lethal response ${ }^{49}$ but it's not clear how such a response can be justified in terms of collective self-defense. For the individuals of the victim nation still have their national community essentially intact.

Baker claims that even the most benign aggressor will threaten the realization of another of Nussbaum's conditions, that being emotional health; more specifically, "[n]ot having one's emotional development blighted by overwhelming fear and anxiety." For Baker, "living under the occupation of some other nation is a condition, even in the most benign cases, that is likely to cause significant levels of fear or at the very least anxiety." ${ }^{50} \mathrm{I}^{\prime} \mathrm{m}$ not convinced, however, that this would necessarily be the case, especially given that the regime is not tyrannical or authoritarian. There may be some fear and anxiety, especially at the outset of the occupation or interference. But I fail to see how such fear and anxiety would be both long lasting and so overwhelming that it stunts emotional development.

The real issue, rather than fear, is being unjustly forced into a posture of extreme deference and dependence. In the final) section of this paper I will argue that even the most benign kind of mitigated aggression unjustly forces a victim nation into such a posture, thus a victim nation can be permitted to lethally defend itself.

\section{LETHALLY DEFENDING ANTI-POWER}

There are two main rival conceptions of liberty or freedom. The traditional conception sees liberty as what Philip Pettit calls anti-power, which is essentially a state of not being subjugated or dominated. The more contemporary conception sees liberty as actual non-interference.$^{51} \mathrm{My}$ goal is simply to contrast these two conceptions of freedom, not argue for the plausibility of one over the other. 
Whether anti-power is genuine freedom or not, I suggest that anti-power is worth lethally defending. I will first discuss the traditional conception and then the more contemporary.

To have freedom is to not be "dominated or subjugated by anyone," it is to not be "defenselessly susceptible to interference by another." ${ }^{52}$ Agent $X$ dominates agent $Y$ to the extent that $X$ has the "(1) capacity to interfere (2) with impunity and at will (3) in certain choices that ... [Y] is in a position to make." ${ }^{53}$ Regarding clause (1), $X$ interferes with $Y$ when $X$ willfully attempts to worsen $Y$ "s "situation of choice." ${ }^{\prime 4}$ This means that $X$ attempts to either change (reduce) Y's available options, or alter the expected outcomes assigned to those options, or control which outcomes will actually stem from which options. Examples of interfering behaviors include manipulation as well as coercing the body or will of another. ${ }^{55}$

Regarding clause (2), an agent interferes with full impunity when there is no resulting penalty or loss. "The party interfered with has no way of asserting themselves in response, there is no central body to punish the interference, the interferer does not have to justify themselves to the victim or the community at large or renounce any benefit to in order to practice the interference." ${ }^{56}$ And an agent interferes "at will" when they can initiate interference without having to wait for the realization of prior conditions.

Oftentimes the level of domination that an agent has over another is not absolute but rather a matter of degree. Furthermore [and this involves clause (3)], the range or extent of domination can and oftentimes will be limited. What follows are a few relationships that illustrate one agent dominating another even though the "domination is in reduced measure and over a restricted domain": ${ }^{77}$ The husband who is able to beat his insubordinate wife and at most suffer mild rebuke from his neighbors if he were to do so. Outside of the home though, he cannot interfere much with her. The employer, though he cannot control his employees outside of work, is able to fire them on a whim and at most suffer mild embarrassment as a result. And the police officer or bureaucrat who can harass and demean members of the public on pain of receiving a mere "slap on the wrist."

Two points about domination need to be reiterated. First, $X$ can dominate $Y$ without ever actually interfering with $Y$, and without ever being inclined to do so. As stated by Richard Price, "individuals in private life, while held under the power of masters, cannot be denominated free, however equitably and kindly they may be treated." 58 "What constitutes the power relationship is that fact that in some respect the power bearer could interfere arbitrarily, even if they are never going to do so. This fact means that the victim of power acts in the relevant area by leave, explicit or implicit, of the power bearer; it means that they are at the mercy of that person."

Secondly, X can actually interfere with $\mathrm{Y}$ without dominating $\mathrm{Y}$. X can be a constitutional authority (e.g., a police officer or judge) that does not interfere at will or with impunity but rather under conditions specified by a legitimate constitution. These conditions expose their interfering behavior to effective appeal, review, and sanctions. ${ }^{60}$

Now the contemporary conception of freedom. On this conception, freedom is actual non-interference: "to be free is not to suffer compulsion by force, coercion 
by threat, or manipulation by background stage setting." ${ }^{61}$ Interference of a nonsubjugating authority, say through the implementation of a fair and ultimately beneficial (though necessarily coercive) rule of law, is restrictive of freedom. Furthermore, on this conception, a dominating agent (e.g., a husband, employer, benign political dictator) is not necessarily restrictive of freedom. Freedom is not abrogated so long as no actual interference is committed..$^{62}$

The foregoing discussion obviously has a bearing on mitigated aggression. A mitigated aggressor does interfere with its victim nation due to the fact that it either threatens to invade or has indeed invaded. The concern though is that as long as it's reasonable to expect that the aggressor will leave the common life sufficiently intact, the level of interference is not egregious enough to permit a lethal response. But mitigated aggressors seek to subjugate their victims even if they don't seek to drastically change their day-to-day lives. A nation that has by force (or threat of force) conquered and set itself up as the ultimate ruling authority has the capacity to interfere with impunity and at will in certain choices that the people of a victim nation are in a position to make. I don't want to suggest that a typical mitigated aggressor that has conquered another nation exercises absolute domination. We can imagine such an aggressive nation being criticized by the world community. And it's dubious to think that such an aggressive nation has the potential to interfere with every choice of those who comprise the victim nation. But seemingly the measure and extent of their domination, in virtue of being the ruling power taken by force (or threat of force), qualifies as being sufficiently egregious. A dominated nation would be susceptible to interference concerning such things as the exploitation of their own natural resources, imposed taxes, the future direction of the nation, and unwelcome cultural influence.

I suggest that A is permitted to kill B if B unjustly threatens to immediately make A's life unfitting for a human being (make it such that it is no longer a human kind of life) for a sufficiently long duration, killing B is the only way to avoid his harm, and any evil that stems from killing B (e.g., harm to bystanders) is not excessive.$^{63}$ Of course there will be uncertainty as to what makes for a life that is not fitting for a human being. It seems to me though that if there is anything in addition to one's life that is worth lethally defending, and most people think that there is, the condition of not being subjugated is such a thing. Being in a position of dependence and deference, not having a genuine security from the arbitrary interference of the aggressive nation, even though no significant actual interference is experienced, seemingly marks the absence of a truly human kind of life. Thus the people of a victim nation can be permitted to lethally defend themselves against mitigated aggression.

Of course one could just deny both the proposed sufficient conditions for lethal self-defense and the idea that being forced to live under an authority that has the capacity to basically interfere with impunity marks a life unfit for a human being. It seems, however, that the burden of proof is on those who would think otherwise.

In what follows I discuss two possible objections. The first objection claims that the domination exemplifying relationships mentioned above don't call for the dominated party to exercise lethal self-defense. The wife surely can't kill her dominating husband, nor can the employee kill his employer. But in response, 
the international scene is essentially a state of nature with no effective and authoritative international police force that can be called upon. Surely a victim nation would be required to pursue all avenues of deterrence and negotiating, but these can fail. Now imagine a state of nature where a man approaches a woman and threatens to harm her severely if she doesn't submit to be married. She'll be treated quite well in the marriage, but he will enjoy a dominating power over her. ${ }^{64}$ Imagine something similar for someone who forces others to work for him. It seems to me that the would-be wife and employees are permitted to lethally respond if that is the only way to avoid subjugation.

A second objection claims that a mitigated aggressor can basically make itself a non-subjugating power. It can constitutionally regulate its own power such that its actions are open to genuine appeal and review. It seems, however, that such a scenario in the real world is unlikely. That an aggressive nation would threaten to kill those of a victim nation is evidence of a profound disrespect of the people it seeks to rule and an unwillingness to be kept in check by them. Any proclamation of a rule of law or constitutional regulation should not be trusted, but rather seen as a mere formality. It's difficult to see an aggressive nation gaining control by military force (or threat of force) and then making it so the people they rule have real power over them, i.e., have genuinely effective means to shield against the real possibility of arbitrary and extensive interference. This it seems is analogous to someone taking your car keys by threat of force but then giving them back to you and asking if he may borrow your car. Or say a man forces a woman into marriage but then gives her full permission to divorce whenever she wanted. Really the only power-relinquishing move that a mitigated aggressor could make that would call into question a lethal response is one that gave the victim nation the power to drive out the aggressor by a mere command. But it's highly unlikely that an aggressor would ever do this. Even if there was an historical precedent of aggressors divesting themselves of power in this way, given what the victim nation stands to lose, it seems that a victim nation in a given case is entitled to not trust any claims to a real relinquishing of power.

I have tried to demonstrate that a plausible case can be given for why a defensive war-conceived of in terms of collective personal self-defense-against mitigated aggression can be proportionate. It's a case that is seemingly the least problematic when compared to rival accounts, primarily because it both addresses the 'benign dictator' objection and it doesn't assume that X can be lethally defended in a way that satisfies the proportionality requirement despite the fact that $X$ by itself is insufficiently valuable to lethally defend. ${ }^{6}$

\section{Endnotes}

1. I am assuming this throughout this paper.

2. For a discussion on mitigated aggression see David Rodin's award winning book, War and Self-Defense (Oxford: Oxford University Press, 2002), 132-4. And, David Rodin, "Beyond National Defense" Ethics and International Affairs 18.1 (2004): 95. Rodin uses the term 'conditional aggression' as opposed to 'mitigated aggression.' 
3. David Rodin, "Beyond National Defense," 95. Richard Norman also holds this view. See his Ethics, Killing and War (Cambridge: Cambridge University Press, 1995), 120-56.

4. See Douglas Lackey, The Ethics of War and Peace (Englewood Cliffs, NJ: Prentice Hall, 1989), 40-1.

5. Thomas Hurka, "Proportionality in the Morality of War," Philosophy and Public Affairs 33 (2005): 35-40; Lackey, The Ethics of War and Peace, 40-1

6. Hurka, "Proportionality in the Morality of War," 45-6.

7. There are complicated questions that arise concerning the evils of war and how they are to be weighed in the proportionality calculus. For example, are the deaths of the defending nation's civilians and soldiers worse than the deaths of the civilians and soldiers of the aggressive nation? See Hurka, "Proportionality in the Morality of War," 59-64. For the purposes of this paper I set these questions aside.

8. Ibid., 40.

9. See Jeff McMahan and Robert McKim, "The Just War and the Gulf War," Canadian Journal of Philosophy 23.4 (December 1993): 502-6. Also see Hurka, "Proportionality in the Morality of War," 41.

10. McMahan and McKim, "The Just War and the Gulf War," 503-6. Hurka, "Proportionality in the Morality of War," 41.

11. McMahan and McKim, "The Just War and the Gulf War," 504-5; Hurka, "Proportionality in the Morality of War," 42.

12. See Jeff McMahan, "War as Self-Defense," Ethics and International Affairs 18.1 (2004): 77-9. Hurka, "Proportionality in the Morality of War," 42

13. Rodin, War and Self-Defense, 40.

14. But still there are government and military officials that comprise a portion of the victim state that have the authority to coordinate the collective exercise of everybody's right of self-defense. They are the ones that direct when, where, and how much force is to be used. Do these officials have the power to make the joint action (roughly the aggregate of coordinated acts of self-defense) - unbeknown to many of the persons carrying out the joint action-one where the goals include deterrence and incapacitation? It's difficult to know what to say here. They seemingly don't have the authority to do this. If the goals include deterrence and incapacitation, then it looks like punishment is taking place rather than self-defense. And it's questionable whether the governmental and military leaders (and the soldiers) have the authority to exact punishment. But I am agnostic regarding their authority to give the joint action other goals besides these.

15. See Rodin, "Beyond National Defense," 96. And of course if the threat to international security consists in possibly committing mitigated aggression then by hypothesis the threat is not egregious enough to wart nt lethal force.

16. See McMahan, "War as Self-Defense," 78

17. Such an individual clearly seems possible to me. Thanks to Guy Sela for helpful conversation here.

18. How likely does it have to seem to me that my assailant won't kill me before I am obligated to capitulate and hand over my quarter (or any other thing that is clearly not worth lethally defending)? This is a difficult question that can't be fully answered here. $\mathrm{I}$ 'm inclined to think that only near certainty creates such an obligation. Some may claim that near certainty in cases like this is extremely rare, thus in the vast majority of cases a victim is permitted to kill her assailant. If this claim is true I don't see how it supports the argument from anticipation. If near certainty cannot be achieved then it seems we have a standard case of self-defense: lethal force is employed in order to save one's own life. 
SELF-DEFENSE, PROPORTIONALITY, DEFENSIVE WAR, AND MITIGATED AGGRESSION

Should a victim kill her assailant and yet it is somehow found out that despite appearances the assailant would have never killed the victim, it seems the victim would have acted wrongly yet ought to be morally excused.

19. I see no independent reason to think that this is false.

20. I say a bit more about employing lethal self-defense in a state of nature

21. Hurka, "Proportionality in the Morality of War," 51-7.

22. This right of political self-determination, for Hurka, is understood as the right to participate in a democratic process such that you have the power to choose what laws are passed and who is to serve as a governmental official.

23. Hurka, "Proportionality in the Morality of War," 53-4.

24. Hurka, in a footnote (see 53n28) cites and seemingly endorses other theorists who claim that rights have thresholds; for example, Samantha Brennan and F. M. Kamm.

25. Samantha Brennan, "Thresholds for Rights," The Southern Journal of Philosophy 33 (1995): 143-5. Note that Brennan seemingly doesn't require that a person who justifiably has her right infringed be bothering or aggressive towards the group of people who would be spared harm upon having the right infringed. Bystanders, for example, could seemingly have their right to not be punched in the nose justifiably infringed if that somehow kept a thousand people from experiencing a headache. See p. 152. Hurka doesn't seem to go this far; only aggressors can justifiably have their rights infringed.

26. Hurka, "Proportionality in the Morality of War," 53.

27. Ibid., 54-5.

28. Ibid., 56

29. Ibid., 56-7.

30. Ibid., 56 .

31. It's been suggested that the 'large in size' clause doesn't accurately capture Hurka's view. I fail to see how it doesn't. But even if the clause is dropped, my objections against Hurka still seemingly hold.

32. Or whatever country fits the bill of being a large democracy.

33. Deane-Peter Baker, "Defending the Common Life: National-Defence After Rodin," Journal of Applied Philosophy 23.3 (2006): 259-75.

34. See ibid., 265-6 for these functions. Baker's list of functions deviates slightly from Nussbaum's list.

35. Ibid., 264-5

36. Ibid, 268

37. For an argument along these lines see Rodin, War and Self-Defense, 154-5.

The idea here is that the level of foreign imposition is to such a degree that even those who are not interested in politics will feel their lives are adversely affected. The foreign laws and policies are not anything they would consent to, even if previously they never casted a vote or officially supported a policy.

38. Michael Walzer, "The Moral Standing of States," Philosophy and Public Affairs 9.3 (Spring 1980): 212-4.

39. Ibid., 212

40. Ibid., 212; quote taken from Norman, 149.

41. Walzer, "The Moral Standing of States," 216.

42. Baker, "Defending the Common Life," 266-7. 
43. David Miller, On Nationality, 10-11, 59. Daniel Bell, Communitarianism and its Critics (Oxford: Oxford University Press, 1993), 90-113. Avishai Margalit and Joseph Raz, "National Self-Determination," The Journal of Philosophy 87.9 (September 1990): 442-7. David Rodin, 149-50.

44. Bell, Communitarianism, 94-5. Also Rodin 149-50.

45. Bell, Communitarianism, 98-9.

46. Miller, On Nationality, 86. Margalit and Raz, “National Self-Determination,” 444.

47. A prime example of this is how the Roman Empire ruled over its conquered subjects.

48. The aggressive nation, say a colonial power, can also exert significant control from afar while leaving the victim nation's common way of life intact.

49. Assuming of course that other conditions are met e.g., the defensive force is a last resort and the resulting damage is not excessive.

50. Baker, "Defending the Common Life," 268.

51. Philip Pettit, "Freedom as Antipower," Ethics 106.3 (April 1996).

52. Pettit, "Freedom as Antipower," 576. Emphasis mine.

53. Ibid., 579.

54. Ibid.

55. Ibid. Also regarding clause (1), a capacity is to be seen as an actual as opposed to a virtual capacity, i.e., a developed capacity that is ready to be exercised, not a yet to be developed capacity. We might say that a slave owner has the actual capacity to interfere with his slaves, while the person who doesn't own slaves but would jump at the opportunity to do so has the virtual capacity to interfere with slaves. See Pettit, "Freedom as Antipower," 580 .

56. Ibid.

57. Ibid., 581, 585.

58. Richard Price, Political Writings, ed. D. O. Thomas (Cambridge: Cambridge University Press, 1991) 77-8. In Pettit, "Freedom as Antipower," 586.

59. Pettit, "Freedom as Antipower," 586.

60. Ibid.

61. Ibid., 596.

62. Ibid., 597

63. I essentially adopt Baker's view on what other than one's life is valuable enough to lethally defend. Though I am agnostic as to whether everything on his (Nussbaum's) list has such a worth.

Richard Norman in, Ethics, Killing and War, suggests that something is worthy of lethal defense only if it, like life itself, is "irretrievable" once it is taken or destroyed. The dangers faced by a victim, if she is justified in killing her attacker, must be "final and irreversible" in the sense that there is no possibility of future redress. The rapist, enslaver and kidnapper threaten dangers that meet this criterion (128-9). It's not clear though in mind is the possibility of compente in mind is the possibity " comped (say monetarily) after being enslaved or raped. Whatever Norman has in mind, he suggests that there is the possibility of future redress for a victim nation-state that has been conquered by a mitigated aggressor. For an occupied victim nation that has been denied it's 'common way of life' always has hope that there will be a future revival and flourishing of its political life (137-8). But if this is the case, it's not clear that the impossibility of "future redress" is a requirement on whether something has sufficient worth to lethally 
SELF-DEFENSE, PROPORTIONALITY, DEFENSIVE WAR, AND MITIGATED AGGRESSION

defend. For surely a people that have been enslaved can have hope that one day they will be able to throw off their yoke of slavery and regain their freedom. But Norman (and most

people) wouldn't want to claim that the freedom that has been taken away from them is not valuable enough to lethally defend.

64. Surely the practice of arranged marriages complicates things a bit. I'm envisioning someone who is under no cultural expectation that someone other than herself will determine who her spouse will be.

65. Thanks to Matt Hanser for helpful discussion regarding this paper 